\title{
ASPECT OF FISCAL CONSOLIDATION: EVIDENCE FROM SERBIA
}

\author{
Branimir Kalaš*, Jelena Andrašić, Miloš Pjanić \\ University of Novi Sad, Faculty of Economics, \\ Segedinski put 9-11, Subotica, Serbia
}

\begin{abstract}
:
In contemporary market conditions facing continuous debt crisis, the notion of fiscal consolidation is one of potential solutions for solving the main economic issues in any country. As regards fiscal consolidation, it necessary to point out to the importance of developing strategies aimed at minimizing deficit and debt level. Serbia is among those countries in which irrational spending is widely present with unfavourable tendency regarding the aspect of production and consumption. Over the past 25 years, Serbia has spent much more than it has produced, which has led to large budget deficits and debt level. The aim is to point out to the concept of fiscal consolidation and its implementation in Serbia, while the subject of this paper is to present the package of measures and strategies defined by the government of the Republic of Serbia and the Fiscal Council Program.
\end{abstract}

\section{Key words:}

fiscal consolidation, strategy, measures, balance.

\section{INTRODUCTION}

If we observe the transition period of 2001, Serbian economy had a long-run episode of intensive and slow growth. The first transition years included post-conflict reconstruction, structural reforms and foreign direct investments which led to rapid economic growth with an average rate of $5.9 \%$ and a better state of public finances. Fiscal deficit and public debt were moderate and lower until 2008, but the global economic and financial crisis led to deterioration of these indicators. Fiscal instruments that were available to the government in 2009 were limited, and thus it was necessary to restrain from consumption to ensure investment. The government had a nominal pension freeze in
2009 and 2010 and salaries in the real sector were frozen. In order to achieve infrastructure improvement, capital expenditures were held at the level of previous two years or $4 \%$ of GDP (IMF, 2009). In October 2011, Parliament adopted amendments to the Law on Budget systems, introducing a two-tier structure of fiscal rules. The first rule is designed to limit future fiscal deficit and public debt while the second rule should limit the consumption of essential items, particularly public sector wages and pensions (IMF, 2011). Serbia has struggled with weak and slow growth. The stagnation of economic activity has resulted in falling revenues and increasing expenditures. Also, structural fiscal problems, such as continued support to state-owned companies and inefficient tax administration have been a 
drag on growth. As a result of these pressures, general government fiscal deficits averaged 5.6 percent of GDP a year between 2008 and 2014. This paper reflects the main measures of fiscal consolidation program in Serbia with special emphasis on the key macroeconomic and fiscal indicators within a ten-year period. The authors will try to present the situation before and after taking measures and point out to the relevance of fiscal consolidation. Moreover, the authors wanted to highlight the situation in Serbia from the economic aspect using tables and graphic views which manifest trends in Serbia and provide little contribution to this part of public finance. This contribution is determining facts in Serbian economy and results of the fiscal consolidation program.

\section{LITERATURE REVIEW}

The financial crisis has led to an increase in public debt in developed countries where the average rate of gross government debt exceeds 100 percent of GDP for the first time since World War II (IMF, 2011). Also, it has revealed that there is a need for fiscal consolidation that is more likely to improve the global competitiveness and ensure growth (Rodrik, 2012; Spence, 2012). Numerous studies have dealt with the issue of fiscal consolidation (Giavazzi \& Pagano, 1990; Alesina \& Perotti, 1995; Ardagna, 2004; Hallergerg et al., 2007; Mulas-Granados, 2006; Avellaneda \& Hardiman, 2012). The economist Mulas-Granados (2006) added a political variable as a fact that there is the difference as to whether the government is left or right-oriented. Alesina and Perotti (1995) analyzed the role of coalition government and concluded that substantial fiscal adjustments are less likely than other forms of government.

Fiscal consolidation is determined as the specific policy that should lead to the reduction of government deficits and debt accumulation (OECD, 2011). The creation and implementation of the consolidation plan vary from country to country due to the specific and various circumstances of their economy (Botman \& Honjo, 2006; Leigh, 2010; Berkmen, 2011; Clinton et al., 2011; Taylor et al., 2013, Tapsoba, 2013). Berkmen (2011) induced that fiscal consolidation can't give positive results without structural reforms. Furthermore, fiscal consolidation provides the opportunity to rationalize and enhance the tax systems as well as to get rid of distortion damaging the economy (Princen \& Moure, 2013). Bakker and Christiansen (2014) emphasize that it's notable that fiscal consolidation leads to the genuine improvement in government solvency, while Kataryniuk and Valles (2015) noticed that significant fiscal consolidation may reduce the need for future fiscal operations, raising the current confidence of households and enterprises.

\section{MACROECONOMIC STABILITY AND FISCAL POLICY}

Samuelson and Nordhaus (2001) define fiscal policy as the use of taxation and government spending to influence the economy. The core problems arose from declining revenues despite tax rates increase, continued rise of unsustainably high compulsory spending, with public wages and pension bills being the most relevant components. Also, the costs of resolving the status of public banks and guarantees for loss-making public enterprises represent serious state budget expenditures.

Figure 1 shows that the country should achieve macroeconomic stability using adequate policies and strategies with an emphasis on the implementation of structural reforms. On the other hand, the economy has to stabilize the financial system so that banks and other financial institutions could operate smoothly. Economic growth, financial sector resilience and fiscal sustainability are the key principles that should be present in any country. The strong budget institutional framework is needed to sustain the entire process with the institutional aspects playing a major role in making of fiscal policy (IMF, 2010): 


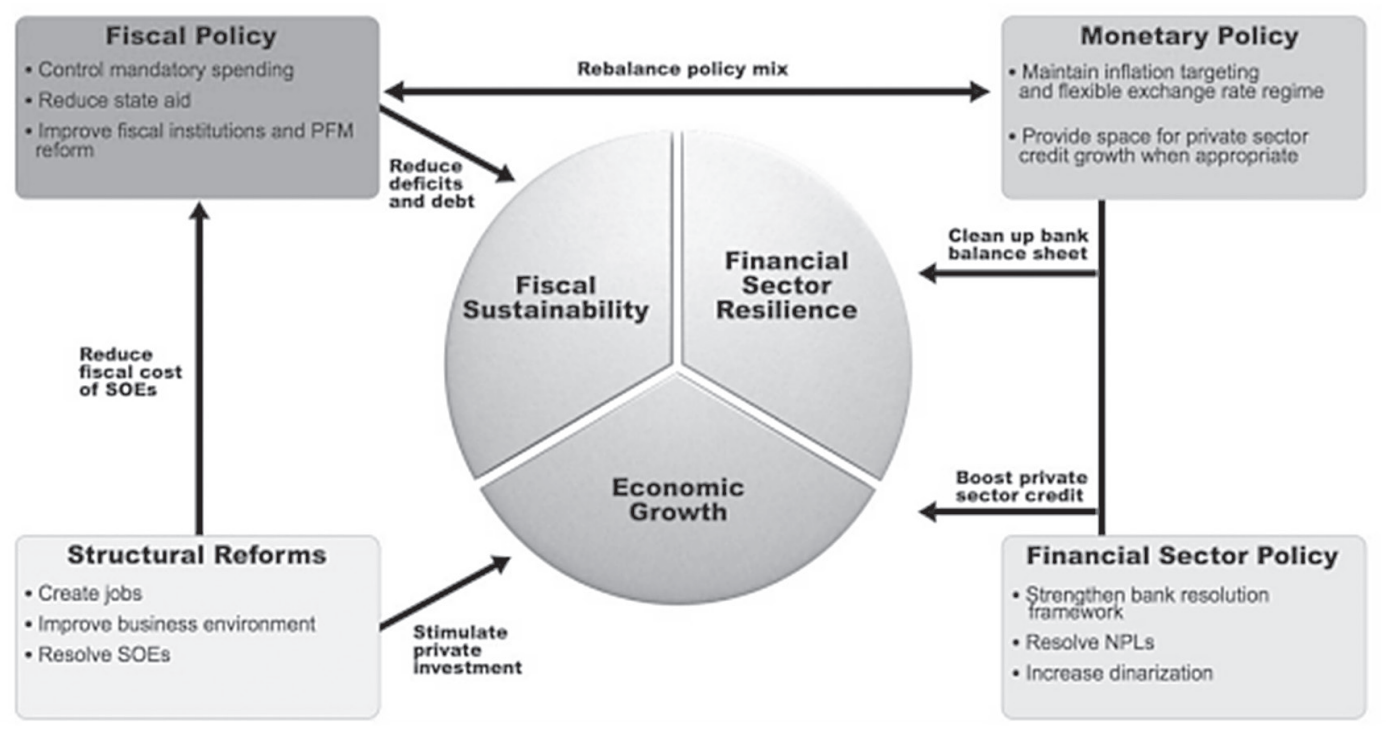

Figure 1. Macroeconomic stability and sustained growth Source: www.imf.org

- understanding the scale of fiscal challenge to planning necessary adjustments;

- creating a respectable consolidation strategy with transparent fiscal rules;

- implementing this strategy through budget.
Table 1 shows the basic economic indicators of foreign trade partners of Serbia in 2015 with the projections for 2016 and 2017. As can be seen, macroeconomic indicators will be better in the next two years. Disinflationary trend in the EU continues during 2015 due to low energy and food

\begin{tabular}{|c|c|c|c|c|}
\hline Indicators (\%) & Country & 2015 & $2016^{*}$ & $2017^{*}$ \\
\hline \multirow{4}{*}{ Real GDP growth } & Italy & 0.9 & 1.5 & 1.4 \\
\hline & Germany & 1.7 & 1.9 & 1.9 \\
\hline & Russia & -3.7 & -0.5 & 1.0 \\
\hline & Eurozone & 1.6 & 1.8 & 1.9 \\
\hline \multirow{4}{*}{ Inflation } & Italy & 0.2 & 1.0 & 1.9 \\
\hline & Germany & 0.2 & 1.0 & 1.7 \\
\hline & Russia & 15.6 & 8.0 & 6.0 \\
\hline & Eurozone & 0.8 & 1.5 & 1.6 \\
\hline \multirow{4}{*}{ Unemployment } & Italy & 12.6 & 12.4 & 11.6 \\
\hline & Germany & 5.1 & 4.8 & 5.2 \\
\hline & Russia & 5.6 & 5.7 & 5.5 \\
\hline & Eurozone & 11.3 & 10.8 & 10.3 \\
\hline \multirow{4}{*}{$\begin{array}{l}\text { Gross government debt of } \\
\text { GDP }\end{array}$} & Italy & 133.8 & 132.7 & 130.0 \\
\hline & Germany & 72.4 & 69.6 & 65.6 \\
\hline & Russia & 16.8 & 17.0 & 22.2 \\
\hline & Eurozone & 94.8 & 93.8 & 92.3 \\
\hline \multirow{4}{*}{$\begin{array}{c}\text { Consolidated fiscal balance } \\
\text { of GDP }\end{array}$} & Italy & -2.7 & -2.2 & -1.6 \\
\hline & Germany & 0.9 & 0.5 & 0.4 \\
\hline & Russia & -2.2 & -2.0 & -0.8 \\
\hline & Eurozone & -2.4 & -2.2 & -1.5 \\
\hline
\end{tabular}

Table 1. Basic economic indicators - foreign trade partners of Serbia Source: European Commission (2015) 
prices and inflation is expected to grow by $0.1 \%$ in 2015. In future, stronger growth in domestic demand and narrowing of the output gap as well as the expected growth in energy prices will contribute to accelerating inflation to $1.5 \%$ in 2016 and $1.6 \%$ in 2017 . On the other hand, unemployment rates should be lower in 2016 and 2017, but the rates will still double in Eurozone (10.8\% and 10.3\%). Petrović et al. (2016) emphasize that high unemployment is one of the biggest structural problems in Serbia where the rate within the population aged 15-64 years was $17.3 \%$, which is among the highest unemployment rates in Europe. Italy has a huge gross government debt exceeding $130 \%$, which is far greater than the defined convergence criteria. Furthermore, Germany doesn't have this problem and its debt is around $70 \%$ with a decreasing tendency in 2016 and 2017, which is quite encouraging data given the fact that the German economy is the strongest in the Eurozone. Finally, consolidated fiscal balance of GDP records a declining trend in the entire observed group of countries where the level of this indicator will be in plus in Germany (expected surplus of $0.4 \%$ of GDP). Thus, it is necessary to precisely define the concept of fiscal balance and consolidation and list their favourable and adverse effects.

Labus and Labus (2016) defined the standard expectations of the fiscal consolidation program and noticed that it squeezes aggregate demand by depressing public and private consumption. Vujović (2016) determined three related thematic areas of fiscal consolidation in Serbia: a) macromonetary and macro-fiscal public debt block, b) financial sector block and growth enabling micro structural block. The first one is focused on price and exchange rate stability, reducing fiscal deficit and public debt, the second one places special emphasis on providing adequate business and consumer financing at competitive interest rates, whereas the third one is directed towards improving the legal and institutional aspects of business environment climate. In the next chapter, the authors shall analyze in detail the theoretical basis of fiscal consolidation and its practical implementation.

\section{FISCAL CONSOLIDATION: THEORY AND INDICATORS}

Guichard et al. (2007) and Barrios et al. (2010), Hagen et al. (2002), Afonso and Jalles (2011) believe that fiscal consolidation is likely to be launched when the government is weak i.e. when there is huge indebtedness. Lowering of high deficit and public debt is the main task for the Serbian government (Labus \& Labus, 2015). Yartey et al. (2012) have presented several options for debt decrease including the following: growth, fiscal consolidation, inflation, privatization, debt restructuring and defaults (Yartey et al., 2012).

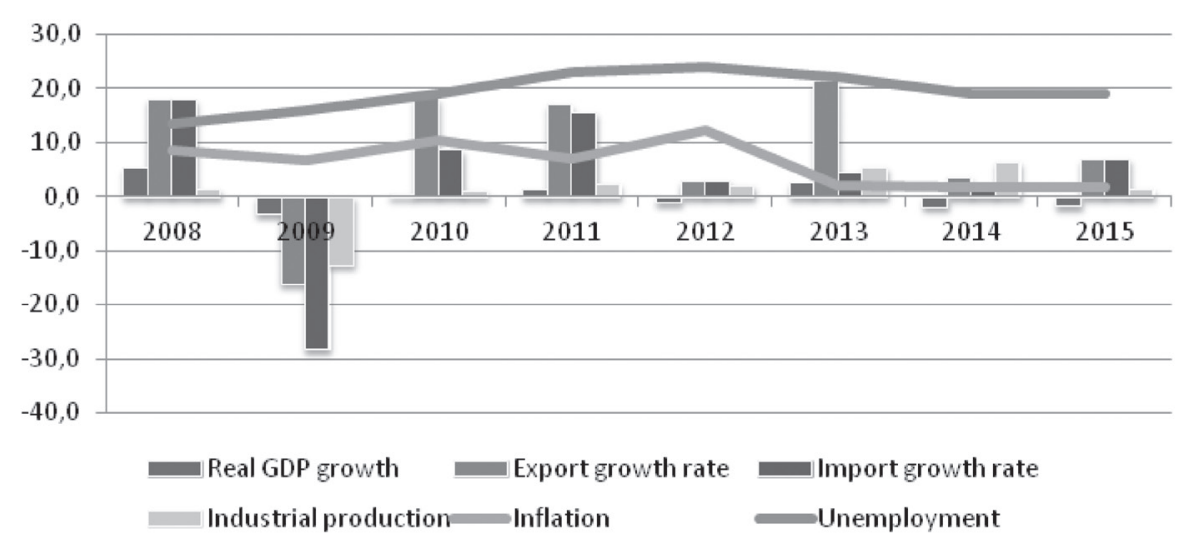

Figure 2. Key macroeconomic indicators in Serbia Source: www.nbs.rs 
Figure 2 manifests the trend of key macroeconomic indicators in Serbia during the period from 2008 to 2015. After opening the economy, Serbia recorded GDP growth rates over 5\%, as a result of an intensive foreign capital inflow and privatization of public enterprises. However, the global crisis and lack of institutional reforms in public administration and enterprises as well as unfavourable business environment lead to lower economic growth in Serbia. During the last two years, there have been negative rates of the observed indicator, i.e. real GDP decrease at the end of 2014 was 1.8\% (Kalaš \& Milošević, 2015). The growth of industrial production is continuous and permanent except in 2009 when there was headlong decline of $12.6 \%$, as a result of the financial crisis. Furthermore, unemployment presents the chronic problem of our economy and the rate has doubled for years and has a growing trend. This indicators grew by $10.3 \%$ only in the period 2008 -
2012 due to deterioration of the world economy, but also because of the structural problems and rigid legislation and unreformed labor markets. Gligorov (2015) noticed that Serbia entered the recession process in 2014 because of fiscal consolidation and export stagnation.

Figure 3 shows the trend of public debt and budget deficit, as two main fiscal indicators in every economy for the period from 2008 to 2015 in Serbia. As we can see, public debt has recorded a growing tendency, especially in the period from 2009 to 2012, when this parameter increased.

In October 2015, debt reached a record degree of $72.9 \%$, which is 44.9 percent higher compared to the beginning of the period. On the other hand, the budget deficit is growing from year to year exceeding 6\% of GDP in 2012 and 2014. However, the deficit was reduced as a result of adjustments to public finances within the fiscal consolidation package and arrangements with the IMF.

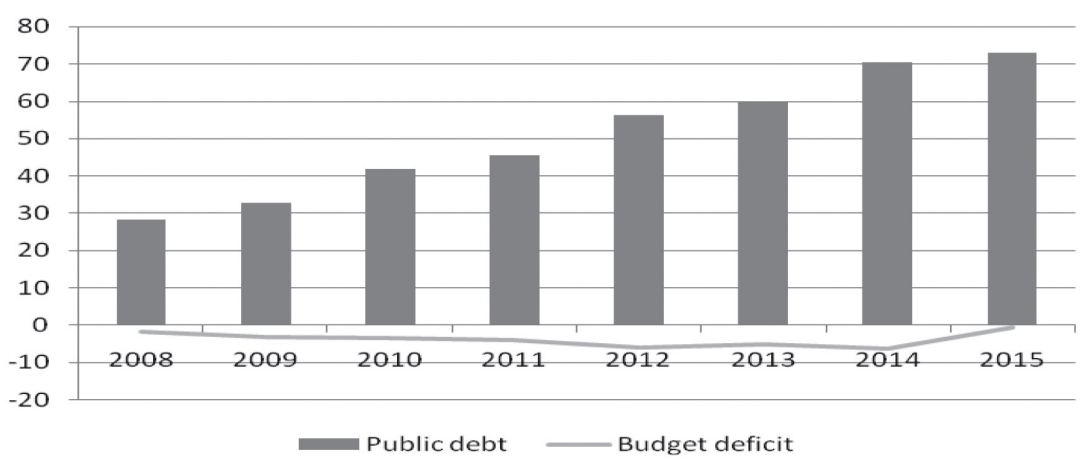

Figure 3. Key fiscal indicators in Serbia

Source: www.nbs.rs

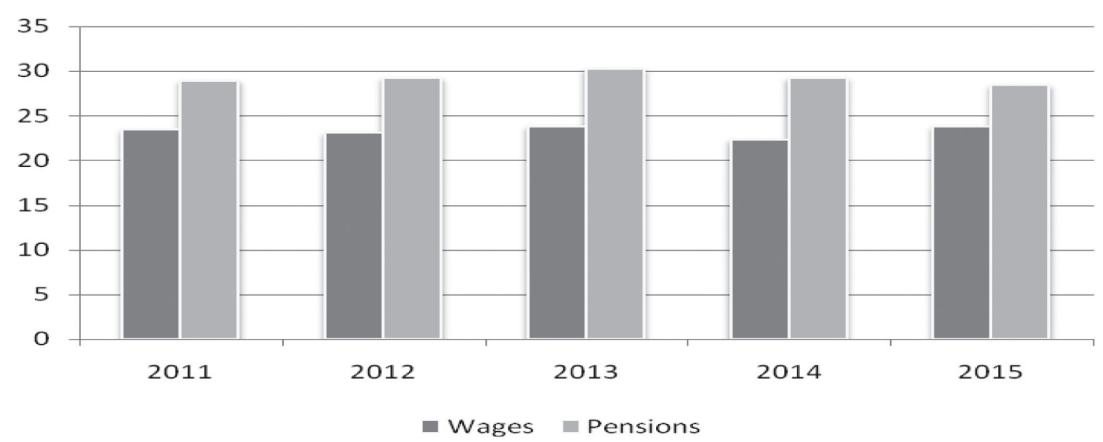

Figure 4. Budget deficit - structural expenses

Source: Ministry of Finance (2015) 
Figure 4 reflects the trend of wages and pensions as structural expenses in the Serbian budget where the level of wages increased by $0.4 \%$, i.e. from $23.4 \%$ to $23.8 \%$, while the share of pension funds reduced by $0.5 \%$, i.e. from $28.9 \%$ to $28.4 \%$ although in 2013 this category accounted for one third of the budget, i.e. $30.2 \%$.

Figure 5 shows the structure of budget deficit in terms of monetary expenditures for wages and pensions as the prevalent components in the public finance system of Serbia. They make more than $50 \%$ of the entire budget, which confirms the relevance of these expenditures. The share of wages and pensions at the end of 2015 was $52.20 \%$, which is by $0.7 \%$ higher compared to 2014 .

Important fiscal consolidation measures were adopted with the budget rebalances in 2012 and their implementation continued in 2013. This policy has primarily been to the revenue side and is related to tax rate changes as well as elimination of significant number of parafiscal levies. On the expenditure side, the most important measure was limiting the growth of public sector wages and pensions where these components are reduced for

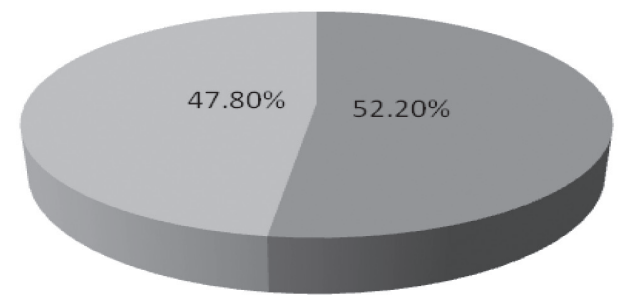

Wages and pensions $\quad$ Other expenditures

Figure 5. Wages and pensions shares of budget 2015

Source: www.mfin.gov.rs

\begin{tabular}{|c|c|c|}
\hline \multirow{2}{*}{$\begin{array}{l}\text { Consolidation duration } \\
\text { and deficit trend }\end{array}$} & $2012-2014$ & 2015-2017 \\
\hline & 2 years: from $6.5 \%$ to $8.5 \%$ of GDP & 3 years: from $8.5 \%$ to below $3 \%$ of GDP \\
\hline Public sector wages & Reduced indexation; solidarity tax & Reduction for $15 \%(10 \%)$ \\
\hline Public sector employment & Limit employment & Rationalization employment \\
\hline Pensions & $\begin{array}{l}\text { Reduced indexation; introducing 13th } \\
\text { pension }\end{array}$ & Reduction for $15 \%(12 \%)$ \\
\hline $\begin{array}{l}\text { Public investments, } \\
\text { subsidies and other } \\
\text { expenditures }\end{array}$ & $\begin{array}{l}\text { Expenditure's growth for banks, public } \\
\text { companies, subsidies; non-execution of } \\
\text { investments }\end{array}$ & $\begin{array}{l}\text { Expenditure's decrease for public } \\
\text { companies, a former social companies, } \\
\text { public investment increase }\end{array}$ \\
\hline \multirow{2}{*}{ Value Added Tax } & Standard rate $18 \%$ to $20 \%$ & Standard rate $20 \%$ to $22 \%$ \\
\hline & Lower rate $8 \%$ to $10 \%$ & Lower rate $10 \%$ to $11 \%$ \\
\hline Income tax & Corporate income tax from $10 \%$ to $15 \%$ & - \\
\hline Excise & Increase & - \\
\hline Structural reforms & Without reforms & $\begin{array}{l}\text { Pension, labor laws and privatization, } \\
\text { restructuring of public companies and } \\
\text { public administration }\end{array}$ \\
\hline
\end{tabular}

Table 2. Fiscal Council proposal

Source: Fiscal Council (2014) 
employees with earnings exceeding 60.000 RSD and a hiring freeze. The measures of fiscal consolidation significantly determine the trend of macroeconomic aggregates in the future, especially the trend of GDP and private consumption. Moreover, measures relating to salaries and pension cuts will have double impact on the overall level of general government revenues (Fiscal Council, 2014):

- Nominal decrease of salaries and pensions in the public sector will have adverse effects on the real level of personal consumption, which will be partially compensated by the trend of salaries into the private sector;

- Projected level of inflation with the trend of the real level of private consumption leads to stagnation of a nominal level of consumption as a determinant of indirect taxes collection in 2015.

- Reduction of salaries in the public sector directly affects the trend of the level of direct taxes. Also, decrease of salaries in parts of the public sector that aren't financed directly from the budget of Serbia will affect the revenue side, by showing the anticipated savings on the revenue side as part of nontax revenues;

- The assumption is that the consumption of excise goods is inelastic and that quantitatively expressed trend of consumption is autonomous in relation to the overall level of spending. The trend of prices of these products directly and largely affects the volume of grey economy;

- Efficiency of parts of the public sector will cause a higher payment received from public companies in the future and together with the introduction of a new category of dedicated revenues in the forms of fees for mandatory strategic oil reserves will affect the amount of total tax revenues.

The economic restructuring of the Serbian economy will be notably supported by the decline of irrational public expenditures and adequate model of investing funding, which would boost the economic growth. Therefore, fiscal policy has the key role in defining the optimum relationship between expenditures and revenues in the budget and if there is a deficit, the government should enable long-term financing. Also, public debt management represents one of the primary goals in every country and the economy lacking the appropriate strategy would face serious issues.

\section{CONCLUSION}

The economic crisis has had a considerable bearing on the Serbian economy through a sudden inflow of capital due to the global trend of decreased economic activity and aggregate demand. In 2009 and 2010, there was a nominal freeze of pensions and wages in the real sector, given that these two components represent the largest budget expenditures. Furthermore, in the period 20112012, the rules were designed to limit fiscal deficit and debt while still maintaining the wages level in the public sector. With solidarity tax or reduction in net income and temporary suspension of employment until 2015, there was also an increase in VAT rate from $8 \%$ to $10 \%$ with determination of measures to repression of shadow economy. If we observe the year 2016, the data show halved fiscal deficit and it's encouraging in terms of public finances of Serbia. However, the public debt growth is a serious issue in our economy. Over the last two decades, irrational spending of funds on the basis of borrowing has been the common tendency in terms of dealing with public finances. Fiscal consolidation must be set and be even more comprehensive with special emphasis on public enterprises with huge loss. Also, giving guarantees and subsidies for their existence on the market leads to spending large funds in the budget and contributes to the deficit growth. Finally, fiscal consolidation needs to be underpinned by structural reforms as only in this way it is possible to achieve measures and goals of successful adjustment of public finance. 


\section{REFERENCES}

Abbas, S.M.A, \& Velloso, R. (2010). Strategies for fiscal consolidation in the post-crisis world. Washington, DC: International Monetary Fund.

Afonso, A., \& Jalles, J.T. (2011). Economic performance and government size. European Central Bank, ECB Working Paper No. 1399. Retrieved March 30, 2016, from https://www.ecb.europa.eu/pub/pdf/scpwps/ ecbwp1399.pdf?66dfde6960bf90d04469b07de906d880

Alesina, A., \& Perotti, R. (1995). Fiscal Expansions and Adjustments in OECD Countries. NBER Working Paper No. 5214. doi:10.3386/w5214

Amo-Yartey, C.A., Narita, M., Nicholls, G.P. Okwuokei, J.C., Peter, A., \& Turner-Jones, T. (2012). The Challenges of Fiscal Consolidation and Debt Reduction in the Caribbean, IMF Working Paper 12/276. Retrieved March 30, 2016, from https://www.imf.org/ external/pubs/ft/wp/2012/wp12276.pdf

Ardagna, S. (2004). Fiscal Stabilizations: When Do They Work and Why? European Economic Review, 48(5), 1047-1074. doi:10.1016/j.euroecorev.2003.09.010

Avellaneda, S., \& Hardiman, N. (2012). Fiscal politics in time: Pathways to fiscal consolidation, 1980-2012. Dublin: UCD Geary Institute.

Bakker, B.B., \& Christiansen, L.E. (2014). Crisis and Consolidation - Fiscal Challenges in Emerging Europe. Retrieved March 30, 2016, from https://www. oenb.at/dam/jcr.../03_bakker_tcm16-245373.pdf

Barrios, S., Langedijk, S., \& Pench, L. (2010). EU fiscal consolidation after the financial crisis: Lessons from past experiences. Brussels: European Commission, Directorate-General for Economic and Financial Affairs.

Berkmen, S.P. (2011). The impact of fiscal consolidation and structural reforms on growth in Japan. Washington, DC: International Monetary Fund.

Botman, D., \& Honjo, K. (2006). Options for fiscal consolidation in the United Kingdom, Washington, DC: International Monetary Fund.

Clinton, K., Kumhof, D.L., \& Mursula, S. (2011). Deficit Reduction: Short-Term Pain for Long-Term Gain. European Economic Review, 55(1), 118-139. doi:10.1016/j.euroecorev.2010.11.006

European Commission. (2015). European Economic Forecast. Luxembourg: Publication Office of the European Union. doi:10.2765/030941

Fiskalni savet. (2014). Pregled uspešnih fiskalnih konsolidacija u Evropi: mere, efekti i poruke. Retrieved March 30, 2016, from http://www.fiskalnisavet.rs/ doc/analize-stavovi-predlozi/pregled_uspesnih_ fiskalnih_konsolidacija_u_evropi-_mere,_efekti_i_ preporuke.pdf. In Serbian.

Giavazzi, F, \& Pagano, M. (1990). Can severe fiscal contractions be expansionary? Tales of two small European countries. Cambridge, MA: National Bureau of Economic Research.

Gligorov, V. (2015). Serbia: Fiscal consolidation starts, Forecast Report/ Spring 2015, WIIW. Retrieved March 30, 2016, from: http://balkan-observatory. net/countryreports/Serbia.pdf

Guichard, S., Kennedy, M., Wurzel, E., \& Andre, C. (2007). What Promotes Fiscal Consolidation: OECD Country Experiences. Paris: OECD Publishing.

Hallerberg, M., Strauch, R., \& Von Hagen, J. (2007). The Design of Fiscal Rules and Forms of Governance in European Union Countries. European Journal of Political Economy, 23(2), 338-359. doi:10.1016/j. ejpoleco.2006.11.005

International Monetary Fund. (2009). The state of public finances cross-country fiscal monitor. Washington DC: International Monetary Fund.

International Monetary Fund. (2011). Euro area policies: Spillover report for the 2011 Article IV consultation and selected Issues. Washington, DC: International Monetary Fund.

International Monetary Fund. (2015). Republic of Serbia: IMF Country Report No. 15/50. Retrieved March 30, 2016, from https://www.imf.org/external/pubs/ft/ scr/2015/cr1550.pdf

Kalaš, B., \& Milošević, S. (2015). Role of fiscal policy in the function of the economic growth of Serbia. Business Economics, 9(2), 213-231.

Kataryniuk, I., \& Valles, J. (2015). Fiscal Consolidation After The Great Recession: The Role of Composition. Banco de Espana Working Paper No. 1515. doi:10.2139/ssrn.2620608

Labus, M., \& Labus, M. (2015). Policy Mix for Fiscal Consolidation in Serbia: Conditional Forecast Approach. Ekonomika preduzeća, 63(1-2), 17-31. doi:10.5937/ekopre1502017L

Labus, M., \& Labus, M. (2016). From Fiscal Consolidation to Fiscal Optimization. Retrieved March 30, 2016, from http://www.belox.rs/uploads/en/publications/working-papers/wp10-2016-from-fiscal-consolidation-to-fiscal-optimization/WP10_2016_1.pdf

Leigh, D., Devries, P., Freedman, C., Guajardo, J., Laxton, D., \& Pescatori, A. (2010). Will it Hurt? Macroeconomic Effects of Fiscal Consolidation, World Economic Outlook: Recovery, Risk and Re-balancing, 
Chapter 3. Washington, DC: International Monetary Fund.

Ministarstvo finansija Republike Srbije. (2015). Bilten javnih finansija. Retrieved March 30, 2016, from http:// www.mfin.gov.rs/UserFiles/File/bilten\%20javne\%20 finansije/bilten-136\%2018032016.pdf. In Serbian.

Mulas-Granados, C. (2006). Economics, Politics and Budgets: The Political Economy of Fiscal Consolidations in Europe. London: Palgrave Macmillan.

National Bank of Serbia. (2013). Statistics. Retrieved March 30, 2016, from http://www.nbs.rs/internet/ english/80/index.html

OECD. (2011). Fiscal consolidation: Targets, plans and measures. OECD Journal on Budgeting, 11(2), 1567. doi:10.1787/16812336

Petrović, P., Brčerević, D., \& Milić, S. (2016). Economic recovery, employment and fiscal consolidation: Lessons from 2015 and Prospects for 2016 and 2017. Retrieved March 30, 2016, from http://www.fiskalnisavet.rs/doc/istrazivacki-radovi/FC\%20working\%20paper\%20-\%20KBF\%202016\%20ENG.pdf

Princen, S., \& Mourre, G. (2013). The role of tax policy in times of fiscal consolidation: Proceedings of the workshop organised by the Directorate General for Economic and Financial Affairs held in Brussels on 18 October 2012. Retrieved March 30, 2016, from http://ec.europa.eu/economy_finance/publications/ economic_paper/2013/pdf/ecp502_en.pdf
Rodrik, D. (2012). No More Growth Miracles. Retrieved March 30, 2016, from http://www.project-syndicate. org/commentary/no-more-growth-miracles-bydani-rodrik

Samuelson, P.A., \& Nordhaus, W.D. (2001). Economics. Boston: McGraw-Hill.

Spence, M. (2011). The next convergence: The future of economic growth in a multispeed world. New York: Farrar, Straus and Giroux.

Tapsoba, S.J.A. (2013). Options and strategies for fiscal consolidation in India. Washington, DC: International Monetary Fund.

Taylor, J., Cogan, J., Wieland, V., \& Wolters, M. (2013). Fiscal Consolidation Strategy. Journal of Economic Dynamics and Control, 37(2), 404-421.

Von Hagen, J., Hallett, A.H., \& Strauch, R. (2002). Budgetary consolidation in Europe: Quality, economic conditions and persistence. Journal of the Japanese and International Economies, 16(4), 512535. doi:10.1006/jjie.2002.0516

Vujović, D. (2016). Serbia: Fiscal Consolidation Program Design and Political Economy Issues. Ekonomika preduzeća, 2016, 1-13. Retrieved March 30, 2016, from http://ses.org.rs/upload/Ekonomika\%20preduzeca\%201-2-2016.pdf

\section{ASPEKT FISKALNE KONSOLIDACIJE U SRBIJI}

\section{Rezime:}

U savremenim tržišnim uslovima gde je dužnička kriza veoma zastupljena, pojam fiskalne konsolidacije predstavlja jedan od mogućih rešenja za prevazilaženje glavnih problema u privredi jedne zemlje. Kada govorimo o fiskalnoj konsolidaciji, neophodno je da se ukaže na značaj izrade strategija koje imaju za cilj smanjenje deficita i nivoa duga. Srbija se ubraja u zemalje u kojima je neracionalna potrošnja široko rasprostranjena sa nepovoljnom tendencijom sa stanovišta proizvodnje i potrošnje. U proteklih dvadeset pet godina, Srbija je trošila mnogo više nego što je proizvodila, što je dovelo do ogromnog budžetskog deficita i visokog nivoa duga. Cilj ovog rada jeste da prikaže značaj koncepta fiskalne konsolidacije i njegove primene u Srbiji, dok se predmet rada ogleda u predstavljanju paketa mera i strategija definisanih od strane Vlade Republike Srbije, kao i programa predloženog od strane Fiskalnog saveta.

\section{Ključne reči:}

fiskalna konsolidacija,

strategija,

mere,

ravnoteža. 